\title{
Student-oriented teaching practices and educational equality: a population-based study
}

\section{Aino Saarinen ${ }^{1,2}$, Jari Lipsanen ${ }^{1}$, Mirka Hintsanen ${ }^{2}$, Minna Huotilainen ${ }^{3}$, Liisa Keltikangas-Järvinen ${ }^{1}$}

${ }^{1}$ Department of Psychology and Logopedics, Faculty of Medicine, University of Helsinki, Finland

${ }^{2}$ Research Unit of Psychology, University of Oulu, Finland

${ }^{3}$ Faculty of Educational Sciences, University of Helsinki, Finland

\section{Finland}

Correspondence: Aino Saarinen. Full postal address: Department of Psychology and Logopedics, Haartmaninkatu 3, P.O. Box 21, 00014 University of Helsinki, Finland. E-mail: aino.i.saarinen@ helsinki.fi, Tel.: +35844 3071204

(C) Universidad de Almería and Ilustre Colegio Oficial de la Psicología de Andalucía Oriental (Spain) 


\begin{abstract}
Introduction. Evidence has remained scarce whether teaching practices might be linked to students' educational equality. This study investigated (i) whether student-oriented teaching practices are associated with students' learning outcomes in mathematics, and (ii) whether student-oriented teaching might increase equality in learning outcomes between students with different backgrounds.
\end{abstract}

Method. We used the Finnish PISA 2012 data $(\mathrm{N}=5052-5660)$ that provides a nationally representative sample of the Finnish 15-year-old students. The data were analyzed using structural equation models.

Results. Frequent student-oriented teaching practices were associated with students' weaker learning outcomes in mathematics. The effect of frequent student-oriented teaching practices was especially negative among students with risky backgrounds (i.e. risky family structure, low family wealth, low maternal education, immigrant status, student's previous truancy behavior at school). Our additional analyses showed that also frequent inquiry-based teaching practices were related to weaker learning outcomes in science.

Discussion and Conclusion. In conclusion, student-oriented teaching practices appear to be linked with students' weaker learning outcomes in comprehensive school. Student-oriented teaching may expand the gaps in learning outcomes between students coming from different backgrounds.

Keywords: Teaching practices; Learning outcomes; Educational equality; Family background; Comprehensive school 


\section{Resumen}

Introducción. La evidencia ha sido escasa sobre la posible relación de las prácticas de enseñanza con la igualdad educativa de los estudiantes. Este trabajo investigó (i) si las prácticas de enseñanza orientada al alumno están asociadas con los resultados de aprendizaje en matemáticas, y (ii) si la de enseñanza orientada al alumno podría aumentar la igualdad en los resultados de aprendizaje entre estudiantes de diferente trasfondo.

Método. Utilizamos los datos finlandeses de PISA 2012 ( $\mathrm{N}=5052-5660)$, que proporcionan una muestra representativa a nivel nacional de los estudiantes finlandeses de 15 años. Los datos se analizaron utilizando modelos de ecuaciones estructurales.

Resultados. La práctica frecuente de la enseñanza orientada al alumno se ha asociado con peor resultados de aprendizaje en matemáticas. El efecto de la práctica frecuente de la enseñanza orientada al alumno fue especialmente negativo entre los estudiantes con factores de riesgo (es decir, familia desestructurada, pobreza familiar, bajo nivel de estudios de la madre, condición de inmigrante, previos comportamientos de absentismo escolar). Nuestros análisis adicionales mostraron que la frecuente práctica de enseñanza basada en la indagación también estaba relacionada con peores resultados de aprendizaje en las ciencias naturales.

Discusión y conclusión. En conclusión, las prácticas de enseñanza orientada al alumno parecen estar vinculadas con peores resultados de aprendizaje de los estudiantes en centros de educación secundaria. La enseñanza orientada al alumno puede ampliar la brecha en los resultados de aprendizaje entre estudiantes de diferentes trasfondos.

Palabras clave: prácticas de enseñanza; Resultados del aprendizaje; Igualdad educativa; Trasfondo familiar; Educación secundaria. 


\section{Introduction}

Educational inequality and school drop-out are known to increase the risk for social marginalization. Previous studies have shown that school achievements predict lower socioeconomic status (Slominski et al., 2011) and higher risk for unemployment in adulthood (Li, 2006). Moreover, school dropout predicts increased risk for psychiatric disorders, suicidality, and criminal behavior (Epstein et al., 2019; Jaggers et al., 2016; Wallin et al., 2019). Additionally, low school performance predicts unfavorable health behavior, for example, substance dependency (Maynard et al., 2015) and excessive alcohol use (Huurre et al., 2010; Pitkänen et al., 2008). Consequently, reducing school drop-out and increasing educational equality are influential societal goals.

In the previous PISA reports (in years 2000-2009), Finland was ranked among the top countries with regard to cognitive learning outcomes. However, more recent PISA tests have shown that Finnish students' learning outcomes have significantly declined (OECD, 2016). In particular, inequality in educational achievements is increasing among the Finnish students (OECD, 2016). For instance, more than 6000 Finnish students do not achieve the curricularelated basic skills in some school disciplines (OECD, 2016). In particular, the inequality between students coming from high or low socioeconomic background has substantially increased (OECD, 2016).

Traditionally, it has been investigated which factors outside the school system might increase or decrease educational equality. For example, it has been found that gender differences (Breen et al., 2010), parental involvement (Hong et al., 2010), or a risky family structure (Hansen \& Gustafsson, 2019) may increase inequality in educational outcomes. However, more research is needed whether there exist factors inside the school system that might increase educational inequality. The aim of this study was to investigate the relationship of student-oriented teaching practices with equality in learning outcomes between students coming from different family backgrounds.

In the recent decades, the school curriculum reforms and educational programs have taken a shift from the traditional teaching approach toward student-oriented teaching strategies across developed countries (e.g. Hurmerinta \& Vitikka, 2011; National Research Council, 2000). In the student-oriented approach, learning is regarded a self-directed and active 
process that is regulated by the students themselves (Furtak \& Kunter, 2012; Kim \& Davies, 2014; Lipowsky et al., 2009). Hence, the teacher's role is to provide opportunities for students to find their individual learning strategies and to carry out their own active investigations (Caro et al., 2016; Furtak \& Kunter, 2012; Lipowsky et al., 2009; Schunk, 2008; Terhart, 2003; Von Secker \& Lissitz, 1999). One fundamental goal of student-oriented teaching is to promote students" "experiential learning" and "deeper activation" (Lipowsky et al., 2009; Furtak \& Kunter, 2012; Kim \& Davies, 2014). In practice, student-oriented lessons commonly include, for example, students' individual choices of learning tasks, group work, discussions among students in the classroom, hands-on activities, and interactive games (Caro et al., 2016; Lipowsky et al., 2009; Mayer, 2004; Sturm \& Bogner, 2008).

When compared to the traditional (teacher-directed) approach, student-oriented teaching is suggested to facilitate "higher-level thinking skills" and "deeper learning" (Bransford, Brown, \& Cocking, 1999). That is, student-oriented teaching is suggested to result in students' better capacities to construct their own insights and to apply the new knowledge to various real-life contexts (Kim \& Davies, 2014; Lord, 2001), instead of recalling facts (Kim \& Davies 2014). Moreover, it has been stated that student-oriented teaching is related to students' higher motivation (Guthrie \& Wigfield, 2000; Sturm \& Bogner, 2008), higher wellbeing at school (Randler \& Bogner, 2006; Schaal \& Bogner, 2005), more pleasant feelings during lessons (Lea et al., 2003), higher personal meaningfulness of school subjects (Schaal \& Bogner, 2005), and better social skills (Lord, 2001).

The relationship of student-oriented teaching with actual learning outcomes has remained a strongly debated topic in the literature (e.g. Cobern et al., 2010; Mayer, 2004; Kirschner, Sweller, \& Clark, 2006; Sweller, 2009). Overall, a variety of studies have suggested that frequent student-oriented teaching strategies may be linked with students' weaker learning outcomes (Albanese \& Mitchell, 1993; Chall, 2000; Furtak \& Kunter, 2012; Gao et al., 2014; Kirschner et al., 2006; Klahr \& Nigam, 2004; Mayer et al., 2004; Moreno, 2004; Schaal \& Bogner, 2005; Sturm \& Bogner, 2008; Tuovinen \& Sweller, 1999).

Finland provides an especially fruitful environment to investigate the association of student-oriented learning methods with learning outcomes. Firstly, the Finnish national curriculum does not define the learning methods of mathematics very strictly but rather gives high freedom and autonomy to teachers (The Finnish National Agency for Education, 2016). 
This creates variance in teaching methods that is necessary in order to conduct investigations. Secondly, in Finland, variation in teaching strategies has also been increased by different teacher education programmes from the 1990s onwards (e.g. traditional teacher education and phenomenon-based programme) that result in teachers with different teaching methods. Thirdly, the rate of student-oriented teaching methods has been increased from the beginning of the 2000s onwards in Finland (e.g. Hurmerinta \& Vitikka, 2011). For example, in the curricula of years 2004 and 2008, there are recommendations about promoting students' selfdirectedness, students' own learning projects, and students' responsibility for their learning goals and processes (The Finnish National Agency for Education, 2004, 2008). Simultaneously with the increasing emphasis on students' self-directedness, the most recent PISA reports have demonstrated that the learning outcomes of the Finnish students have declined, especially in mathematics (e.g. OECD, 2016). Subsequently, it has been discussed whether the curricula reforms promoting student-oriented teaching strategies might be linked with the decline in the PISA results of some countries (e.g. Gao et al., 2014). Thus, the first aim of this study was to investigate whether the frequency of student-oriented teaching is associated with students' mathematical performance in Finland.

The second topic requiring more research is whether student-oriented teaching might have differential effects on learning outcomes depending on student's background characteristics. Essentially, one core assumption of the recent curricula reforms is that student-oriented teaching might increase equality in the learning outcomes between students with different cognitive abilities and different socioeconomic backgrounds (Von Secker \& Lissitz, 1999). Later on, this assumption has been questioned. For example, it has been suggested that students with low school achievements and students coming from low-SES families or minorities might benefit less from student-oriented teaching strategies (Connor, Morrison, \& Katch, 2004; Kirschner et al., 2006; Von Secker \& Lissitz, 1999; Zohar \& Dori, 2003). However, evidence is still limited, so that the need for studies examining this topic more thoroughly has been clearly expressed (e.g. Gao et al., 2014; Klahr \& Nigam, 2004; Kyriakides et al., 2013).

\section{Objectives}

The first aim of this study was to investigate whether the frequency of student-oriented teaching practices is associated with students' learning outcomes in mathematics. The second aim was to examine whether student-oriented teaching might increase or decrease equality in learning outcomes between students with and without risky background characteristics. That 
is, whether the effect of student-oriented teaching on students' mathematical performance might be modified by background characteristics (i.e. gender, immigrant status, risky family structure, family socioeconomic factors, and student's previous truancy behavior at school). We used the Finnish PISA 2012 data that provides a large nationally representative sample of the Finnish 15-year-old students. The findings have societal relevance also outside Finland because student-oriented teaching strategies have been actively implemented in a variety of countries (e.g. Hurmerinta \& Vitikka, 2011; National Research Council, 2000), especially because the Finnish educational system is considered by some as one of the international models according to which several countries develop their national educational systems, and also because the Finnish school system is quite similar to other Scandinavian countries and countries of Northern Europe. Further, it is known that children's cognitive architecture and learning processes are very universal (Kirschner et al., 2006; Sweller, 2009).

\section{Method}

\section{Participants}

We used the Finnish PISA (Programme for International Student Assessment) 2012 data. The PISA sample was selected via two phases. Firstly, in each country, it was selected at least 150 national schools that were teaching students within the target age group (aged between 15 years and 3 months and 16 years and 2 months, and at grade 7 or higher). Secondly, from each included school, on average 35 students within the target age group were randomly selected. The main exclusion criteria for individual students were as follows: students with an intellectual or functional disability; students who were unable to follow the instructions of the test; and students with insufficient assessment language skills. In Finland, altogether Finnish students participated in the PISA 2012. A more detailed description of the sampling and design of the PISA 2012 is available elsewhere (OECD, 2014). In the analyses of this study, we included all the participants with data available on learning outcomes, teaching methods, and control variables (age, gender, parental socioeconomic status). Hence, the final sample size was $N=5052-5660$ in the analyses.

\section{Instruments}

Teaching strategies were evaluated on the basis of the triachic model of instructional quality (OECD, 2013). The model includes three factors that have shown cross-cultural validity: structuring practices (i.e. teacher-directed instruction); student-oriented practices; and 
enhanced activities. In the PISA study, the two latter factors were combined into one factor referring to student-oriented strategies (OECD, 2013).

The index of student-oriented teaching was assessed with 4-item questionnaire filled by students. The questionnaire was designed for the PISA study. The statements were as follows: in mathematics lessons, how often the teacher (i) assigns projects that require at least one week to complete; (ii) has students work in small groups to come up with a joint solution to a problem or task; (iii) the teacher gives different work to classmates who have difficulties learning and/or to those who can advance faster; and (iv) the teacher asks students to help plan classroom activities or topics. The statements were rated with a 4-point scale ranging from 1 (every lesson) to 4 (never or hardly ever). The index of student-oriented teaching was scaled so that a higher value of the index referred to more frequent student-oriented teaching practices.

The index of teacher-directed instruction was assessed with a 5-item questionnaire designed for the PISA study and rated by students. The items measured how often the teacher in mathematics lessons (i) sets clear goals for student learning; (ii) sets clear goals for student learning; (iii) the teacher asks students to present their thinking or reasoning at some length; (iv) the teacher asks questions to check whether students understood what was taught; and (v) the teacher tells students what they have to learn. The items were answered with a 4-point scale ranging from 1 (every lesson) to 4 (never or hardly ever). The index of teacher-directed instruction was scaled so that a higher value of the index referred to more frequent teacherdirected instruction.

Mathematical literacy referred to 3 types of mathematical abilities. Firstly, it measured students' abilities to formulate situations mathematically (e.g. to recognize mathematical structure of problems situated in a real-world context; identify assumptions behind mathematical modelling; use appropriate variables, symbols, diagrams etc.). Secondly, mathematical literacy measured students' abilities to employ mathematical concepts, facts, procedures, and reasoning (e.g. to use mathematical tools, rules, and algorithms to find mathematical solutions; manipulate numbers, geometric representations, and algebraic expressions; extract information from graphical data, diagrams, and graphs). Thirdly, mathematical literacy measured students' abilities to interpret, apply, and evaluate mathematical outcomes (e.g. to inter- 
pret and evaluate the reasonableness of a mathematical result in the various real-world contexts; understand and critique the limits of mathematical concepts and solutions).

The PISA 2012 contained altogether 270 minutes of mathematical literacy material. The material was arranged in nine 30-minute clusters. The students completed different combinations of the test items. All the items of mathematical literacy were answered with either open constructed-response (a written response, e.g. writing up the phases how the task was solved), closed constructed-response (a more restricted written response, e.g. single numbers), or selected response (selecting one or more responses from a set of responses). The PISA policy allowed students to use calculators in the test items. A more detailed description of the assessment of mathematical literacy is available elsewhere (OECD, 2013).

The Finnish national curriculum of mathematics for grades 7-9 includes learning goals about e.g. thinking skills, algebra calculations, understanding of mathematical functions, geometric skills, and understanding of statistical likelihoods (The Finnish National Agency for Education, 2016). The national curriculum does not include very strict guidelines for teaching or learning methods (The Finnish National Agency for Education, 2016), providing a high degree of autonomy for teachers.

The index of economic, social, and cultural status (ESCS) was evaluated on the basis of questionnaires filled by students. The index of ESCS included of 3 factors: (1) the highest parental occupation, (2) the highest parental education, and (3) home possessions. Parental occupational status was classified in accord with the ISCO codes (ILO, 2007) and then translated into an international socioeconomic index of occupational status. Parental education was first classified on the basis of ISCED (OECD, 1999), ranging from 0 (no education) to 6 (theoretically oriented tertiary education or post-graduate education). Next, parental educational level was recoded into an estimated number of educational years (for example, in Finland, ISCED level $1=6$ educational years; or ISCED level 5=14.5 educational years). In the index of ESCS, highest parental education referred to highest number of parental educational years between the parents. Home possessions included 4 factors: (i) the number of books at home, (ii) family wealth (electronic devices, room space, and cars at home), (iii) cultural possessions of the family (classical literature, books of poetry, works of art at home); and (iv) educational resources of the family (e.g. a desk, quiet place, and computer for studying at 
home). The statistical estimation of the index of ESCS is described more precisely elsewhere (OECD, 2014).

A cumulative risk score of students' risky background characteristics was calculated, referring to the total number of risk factors in students' background. The cumulative risk score included 6 risk factors that have previously been shown to predict weaker school performance. The risk factors were as follows: immigrant status, risky family structure, previous truancy behavior at school, low family wealth, low maternal education, and male gender.

Immigration status included 3 categories: (i) native students (students whose one parent or both parents were born in Finland; (ii) second-generation immigrant students (students who were born in Finland but whose parent(s) were born in some other country); and (iii) first-generation immigrant students (students who were born in some other country and whose parents were born in some other country). In the present study, immigration status was recoded into 2 categories: $0=$ native students; $1=$ first- and second-generation immigrant students.

Truancy behavior at school was assessed with 3 self-rating items that were fulfilled at the time of PISA tests. The items were as follows: (i) the frequency of coming late for school; (ii) the frequency of skipping whole school day; and (iii) the frequency of skipping classes within school day. The items were rated with a 4-point scale ranging from 1 (none) to 4 (five or more times). When rating the items, students were guided not to count such times of truancy behavior that were not intentional (e.g. resulting from sickness or accident). In the present study, a dichotomous score of truancy behavior was calculated: $0=$ having never come late for school, skipped classes within school day, or skipped whole school day; 1=having at least once come late for school, skipped classes, or skipped whole school day.

Family structure was classified into 2 categories: $0=$ students coming from two-parent families (students living with a father or step/foster father and a mother or step/foster mother); $1=$ students coming from single-parent families (students living with mother/female guardian or father/male guardian) and students who did not live with their parents.

Family wealth was recoded into 2 categories: $0=$ highest $80 \%$ of the sample with regard to family wealth; $1=$ lowest $20 \%$ of the sample with regard to family wealth. Maternal education was classified into two categories: $0=I S C E D$ level 3 or higher; $1=I S C E D$ level 2 or 
lower (primary education or lower secondary education). Gender was classified as follows: $0=$ female; $1=$ male.

Finally, the cumulative risk score was calculated as the sum of the 6 risk factors (immigrant status, risky family structure, truancy behavior at school, low family wealth, low maternal education, and male gender). Hence, the cumulative risk score ranged between 0-6. Since the distribution of the cumulative risk score was skewed toward lower values, we recoded the cumulative risk score as follows: $0=$ no risk factors $(N=768) ; 1=$ one risk factor $(N=1743) ; 2=$ two risk factors $(N=1541) ; 3=$ three risk factors $(N=646) ; 4=$ four or more risk factors $(N=354)$.

\section{Datal Analysis}

The data were analyzed with structural equation models (conducted with STATA SE version 13.0). Students' performance in mathematical literacy was treated as latent factor with 5 plausible values, which were based on Rasch Model, as indicator (manifest) variables. The statistical estimation of the plausible values is described more precisely elsewhere (OECD, 2017a). In model 1, we investigated whether student-oriented teaching was associated with students' mathematical performance in the total sample. That is, we added a regression path from student-oriented teaching to students' mathematical performance. In models 2 , we investigated whether the association of student-oriented teaching with students' mathematical performance was modified by students' risky background characteristics (i.e. immigrant status, risky family structure, truancy behavior at school, low family wealth, low maternal education, and male gender). Specifically, in model $2 \mathrm{a}$, we included regression paths from studentoriented teaching, male gender, and their interaction to students' mathematical performance. Correspondingly, we investigated separately the modifying effect of each other risky background characteristic in models $2 \mathrm{~b}-\mathrm{f}$ (i.e. the modifying effect of immigrant status in model $2 \mathrm{~b}$; truancy behavior at school in model 2c; risky family structure in model $2 \mathrm{~d}$; low family wealth in model 2e; and low maternal education in model 2f). Finally, in model 3, we investigated whether the association of student-oriented teaching with students' mathematical performance was modified by the cumulative risk score (i.e. the total number of students' risky background characteristics). That is, we added regression paths from student-oriented teaching, the cumulative risk score, and their interaction to students' mathematical performance. 
All the models were controlled for age, gender, the index of ESCS (i.e. the index of parental economic, social, and cultural status), and the frequency of teacher-directed instruction.

The statistical fit of the structural equation models was evaluated with the values of the Comparative Fit Index (CFI), the Root-Mean-Square Error of Approximation (RMSEA), and the Tucker Lewis Index (TLI). It has been demonstrated that adequate values of the CFI and TLI range over 0.95, and RMSEA should be less than 0.06 (Hu \& Bentler, 1999). Additionally, lower values of the $\chi^{2}$ test of absolute model fit refer to better goodness-of-fit of the model (Schreiber et al., 2006).

\section{Results}

Descriptive statistics of the study variables are presented in Table 1.

Table 1. Means, frequencies, standard deviations, and ranges of the study variables.

\begin{tabular}{lcccc}
\hline & Mean & SD & Frequency (\%) & Range \\
\hline Age & 15.71 & 0.28 & & $15.25 ; 16.25$ \\
Gender & & & $2842(50.2)$ & \\
$\quad$ Female & & & $2818(49.8)$ & \\
$\quad$ Male & 0.36 & 0.83 & & $-3.88 ; 2.54$ \\
Index of ESCS & & & & $-3.65 ; 2.56$ \\
Teaching style & -0.062 & 0.92 & & $-1.60 ; 3.31$ \\
$\quad$ Teacher-directed instruction & 0.018 & 0.84 & & $204.09 ; 766.64$ \\
$\quad$ Student-oriented teaching & 511.49 & 85.07 & & \\
Mathematical literacy & & & & \\
Risky background characteristics & & & $291(14.0)$ & \\
$\quad$ Immigrant status & & & $911(16.1)$ & \\
$\quad$ Truancy behavior at school & & & $468(8.3)$ & \\
$\quad$ Risky family structure & & & $1446(25.5)$ & \\
$\quad$ Low maternal education & 1.62 & 1.10 & & $0 ; 4$ \\
$\quad$ Low family wealth & & &
\end{tabular}

${ }^{a}$ The mean of the plausible values $1-5$.

Table 2 shows the results of structural equation models, when investigating the association of student-oriented teaching in mathematics lessons with students' mathematical performance in the total sample. The results showed that frequent student-oriented teaching was 
associated with students' weaker performance in mathematical literacy $(\beta=-0.25, p<.001)$, when controlling for age, gender, and the index of ESCS (parental socioeconomic factors), and the frequency of teacher-directed instruction.

Table 2. The standardized regression coefficients $(\beta)$ with $95 \%$ confidence intervals $(C I)$ of structural equation models, when predicting mathematical literacy by student-oriented teaching.

\begin{tabular}{lcc}
\hline & \multicolumn{2}{c}{ Mathematical literacy } \\
\cline { 2 - 3 } & \multicolumn{2}{c}{ Model 1 } \\
\cline { 2 - 3 } & $0.060^{* * *}$ & $0.036 ; 0.084$ \\
Age & $0.067 * * *$ & $0.042 ; 0.091$ \\
Gender ${ }^{\mathrm{a}}$ & $0.34^{* * *}$ & $0.32 ; 0.36$ \\
The index of ESCS & $0.091^{* * *}$ & $0.064 ; 0.12$ \\
Teacher-directed instruction & $-0.25^{* * *}$ & $-0.28 ;-0.22$ \\
Student-oriented teaching & & \\
\hline$* p<.05 * * p<.01 * * * p<.001 N=5660$ & \\
${ }^{a}$ Female as the reference group. &
\end{tabular}

Tables $3 \mathrm{a}$ and $3 \mathrm{~b}$ present results of structural equation models, when investigating whether students' risky background characteristics modify the association of student-oriented teaching in mathematics lessons with students' mathematical performance. It was found that the effect of frequent student-oriented teaching on students' mathematical performance was more adverse (i) among boys than among girls $(\beta=-0.095, p<.001)$ (Table 3a); (ii) among first- or second-generation immigrants than among natives $(\beta=-0.055, p<.001)$ (Table 3a); and (iii) among students with truancy behavior at school than among students with no truancy behavior at school $(\beta=-0.053, p<.01)$ (Table 3a); (iv) among students coming from one-parent families or students who were not living with their parents than among students coming from two-parent families $(\beta=-0.032, p<.05)$ (Table $3 b)$; (v) among students coming from lowwealth families than among students coming from wealthier families $(\beta=-0.056, p<.001)$ (Table $3 b$ ), and (vi) among students with low-educated mother than among students with highereducated mother $(\beta=-0.029, \mathrm{p}<.05)$ (Table $3 \mathrm{~b})$. All these findings sustained after controlling for age, gender, the index of ESCS (parental socioeconomic factors), and the frequency of teacher-directed instruction. Frequent teacher-directed instruction, in turn, was associated with students' higher mathematical performance $(\beta=0.091, p<.001)$. 
Table 3a. The standardized regression coefficients $(\beta)$ with $95 \%$ confidence intervals $(C I)$ of structural equation models, when predicting performance in mathematical literacy by student-oriented teaching, male gender, immigrant status, and truancy behavior at school.

\begin{tabular}{|c|c|c|c|c|c|c|}
\hline & \multicolumn{6}{|c|}{ Mathematical literacy } \\
\hline & \multicolumn{2}{|c|}{ Model 2a $(N=5660)$} & \multicolumn{2}{|c|}{ Model 2b $(N=5631)$} & \multicolumn{2}{|c|}{ Model 2c $(N=5589)$} \\
\hline & $\beta$ & $95 \% \mathrm{CI}$ & $\beta$ & $95 \% \mathrm{CI}$ & $\beta$ & $95 \% \mathrm{CI}$ \\
\hline Age & $0.059 * * *$ & $0.036 ; 0.083$ & $0.050 * * *$ & $0.027 ; 0.073$ & $0.065 * * *$ & $0.041 ; 0.088$ \\
\hline Gender $^{a}$ & $0.067 * * *$ & $0.043 ; 0.091$ & $0.057 * * *$ & $0.034 ; 0.081$ & $0.072 * * *$ & $0.048 ; 0.096$ \\
\hline The index of ESCS & $0.34 * * *$ & $0.32 ; 0.36$ & $0.26 * * *$ & $0.24 ; 0.28$ & $0.33 * * *$ & $0.31 ; 0.35$ \\
\hline Teacher-directed instruction & $0.092 * * *$ & $0.064 ; 0.12$ & $0.11 * * *$ & $0.086 ; 0.14$ & $0.073 * * *$ & $0.046 ; 0.099$ \\
\hline Student-oriented teaching & $-0.18 * * *$ & $-0.22 ;-0.14$ & $-0.19 * * *$ & $-0.22 ;-0.17$ & $-0.20 * * *$ & $-0.23 ;-0.16$ \\
\hline $\begin{array}{l}\text { Gender* } \\
\quad \text { Student-oriented teaching }\end{array}$ & $-0.095 * * *$ & $-0.13 ;-0.059$ & & & & \\
\hline Immigration status $^{\mathrm{b}}$ & & & $0.25 * * *$ & $-0.27 ;-0.22$ & & \\
\hline $\begin{array}{l}\text { Immigration status* } \\
\text { Student-oriented teaching }\end{array}$ & & & $-0.055^{* * *}$ & $-0.082 ;-0.028$ & & \\
\hline Truancy behavior at school $^{c}$ & & & & & $-0.18 * * *$ & $-0.20 ;-0.16$ \\
\hline $\begin{array}{l}\text { Truancy behavior at school* } \\
\text { Student-oriented teaching }\end{array}$ & & & & & $-0.053 * *$ & $\begin{array}{l}-0.090 ;- \\
0.017\end{array}$ \\
\hline
\end{tabular}

$* p<.05 * * p<.01 * * * p<.001$ a Female as the reference group. $b$ Native students as the reference group. $c$ Students with no truancy behavior at school as the reference group.

Note: All the interaction analyses (Models $2 a-c$ ) were run separately so that each risk factor was added to the predictors separately.

Table 3b. The standardized regression coefficients $(\beta)$ with $95 \%$ confidence intervals $(C I)$ of structural equation models, when predicting performance in mathematical literacy by student-oriented teaching, risky family structure, low family wealth, and low maternal education.

\section{Please add a horizontal line below the B estimates (as in other tables)}

\begin{tabular}{|c|c|c|c|c|c|c|}
\hline & \multicolumn{6}{|c|}{ Mathematical literacy } \\
\hline & \multicolumn{2}{|c|}{ Model 2d $(N=5237)$} & \multicolumn{2}{|c|}{ Model 2e $(N=5660)$} & \multicolumn{2}{|c|}{ Model 2f $(N=5530)$} \\
\hline & $\beta$ & $95 \% \mathrm{CI}$ & $\beta$ & $95 \% \mathrm{CI}$ & $\beta$ & $95 \% \mathrm{CI}$ \\
\hline Age & $0.062 * * *$ & $0.037 ; 0.087$ & $0.059 * * *$ & $0.036 ; 0.083$ & $0.056 * * *$ & $0.032 ; 0.081$ \\
\hline Gender $^{\mathrm{a}}$ & $0.070 * * *$ & $0.045 ; 0.095$ & $0.069 * * *$ & $0.044 ; 0.093$ & $0.068 * * *$ & $0.044 ; 0.093$ \\
\hline The index of ESCS & $0.32 * * *$ & $0.30 ; 0.35$ & $0 . .36 * * *$ & $0.34 ; 0.38$ & $0.31 * * *$ & $0.28 ; 0.33$ \\
\hline Teacher-directed instruction & $0.089 * * *$ & $0.060 ; 0.12$ & $0.088 * * *$ & $0.061 ; 0.12$ & $0.092 * * *$ & $0.065 ; 0.12$ \\
\hline Student-oriented teaching & $-0.23 * * *$ & $-0.26 ;-0.19$ & $-0.22 * * *$ & $-0.25 ;-0.19$ & $-0.23 * * *$ & $-0.26 ;-0.21$ \\
\hline Risky family structure ${ }^{\mathrm{b}}$ & $-0.053 * * *$ & $-0.078 ;-0.028$ & & & & \\
\hline $\begin{array}{l}\text { Risky family structure* } \\
\text { Student-oriented teaching }\end{array}$ & $-0.032 *$ & $-0.060 ;-0.0038$ & & & & \\
\hline Low family wealth ${ }^{c}$ & & & $0.063 * * *$ & $0.038 ; 0.089$ & & \\
\hline $\begin{array}{l}\text { Low family wealth* } \\
\text { Student-oriented teaching }\end{array}$ & & & $-0.056 * * *$ & $-0.084 ;-0.029$ & & \\
\hline Low maternal education ${ }^{\mathrm{d}}$ & & & & & $-0.045 * *$ & $-0.083 ;-0.017$ \\
\hline $\begin{array}{l}\text { Low maternal education* } \\
\text { Student-oriented teaching }\end{array}$ & & & & & $-0.029 *$ & $-0.055 ;-0.0030$ \\
\hline
\end{tabular}

$* p<.05 * * p<.01 * * * p<.001$ a Female as the reference group. $b$ Students coming from two-parent families as the reference group. $c$ Student coming from high- or average-wealthy families as the reference group. $d$ Students with middle- or higheducated mothers as the reference group.

Note: All the interaction analyses (Models $2 d-f$ ) were run separately so that each risk factor was added to the predictors separately. 
Finally, Table 4 shows the results of structural equation models, when investigating whether the association of student-oriented teaching with students' mathematical performance was modified by the cumulative risk score (i.e. the total number of students' risky background characteristics). The results revealed that there was a negative interaction effect between student-oriented teaching and the cumulative risk score $(\beta=-0.20, \mathrm{p}<.001)$, when predicting students' mathematical performance. That is, the effect of student-oriented teaching on students' mathematical performance became more negative when the total number of risky background characteristics increased (see Figure 1). This finding was controlled for age, gender, the index of ESCS (parental socioeconomic factors), and the frequency of teacher-directed instruction.

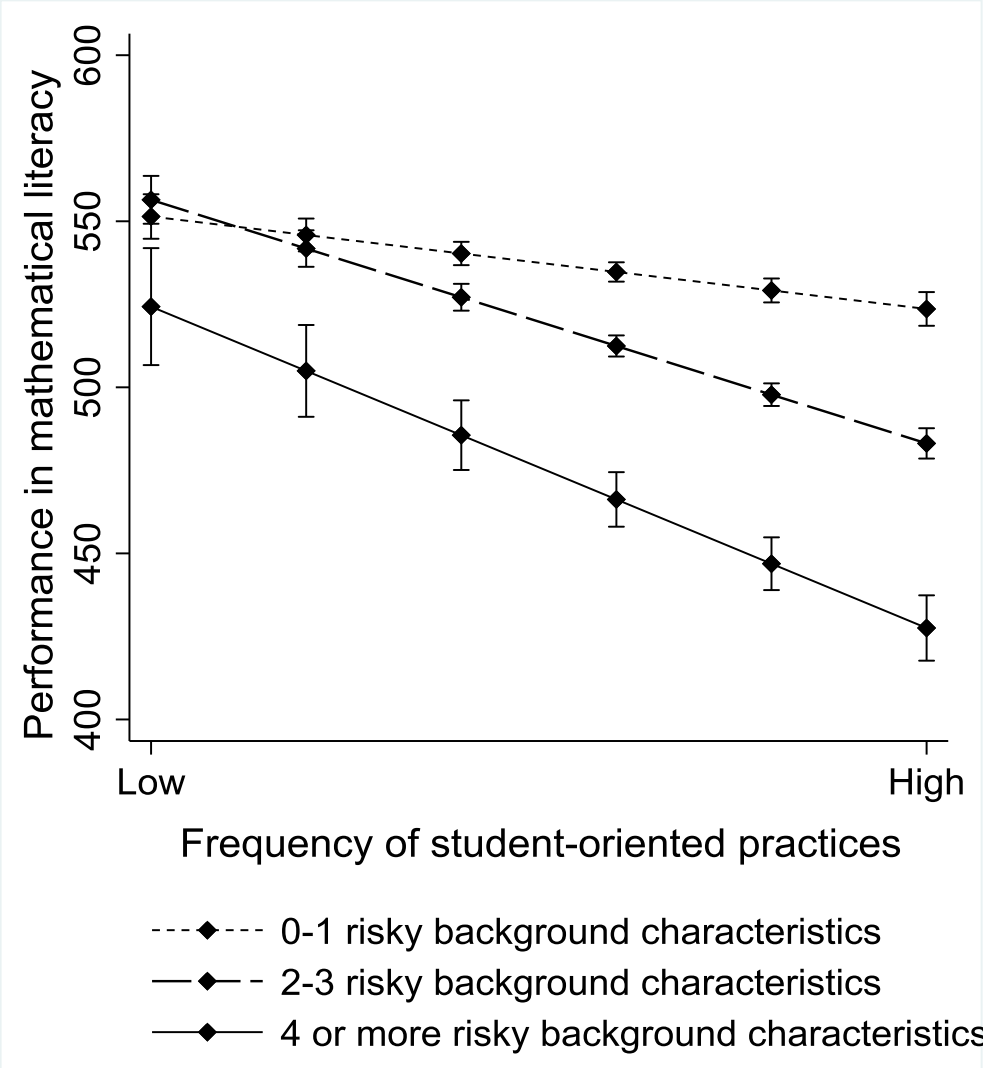

Figure 1. Predicted marginal means with 95\% confidence intervals of students' mathematical performance at different frequencies of student-oriented teaching practices (ranging from 10th percentile to 90th percentile) and at different numbers of risky background characteristics. Adjusted for age, gender, the index of ESCS, and the frequency of teacher-directed practices. 
Table 4 . The standardized regression coefficients $(\beta)$ with $95 \%$ confidence intervals $(C I)$ of structural equation models, when predicting mathematical literacy by student-oriented teaching and the cumulative risk score.

\begin{tabular}{lcc}
\hline & \multicolumn{2}{c}{ Mathematical literacy } \\
\cline { 2 - 3 } & \multicolumn{2}{c}{ Model 3 } \\
\cline { 2 - 3 } & $0.057 * * *$ & $0.032 ; 0.082$ \\
\hline Age & $0.16^{* * * *}$ & $0.13 ; 0.18$ \\
Gender & $0.25^{* * *}$ & $0.22 ; 0.27$ \\
The index of ESCS & $0.092^{* * *}$ & $0.063 ; 0.12$ \\
Teacher-directed instruction & $-0.053^{*}$ & $-0.10 ;-0.0038$ \\
Student-oriented teaching & $-0.20^{* * *}$ & $-0.23 ;-0.17$ \\
Cumulative risk score & & \\
Cumulative risk score* & & \\
\multicolumn{1}{c}{ Student-oriented teaching } & $-0.20^{* * *}$ & $-0.25 ;-0.15$ \\
\hline
\end{tabular}

$* p<.05 * * p<.01 * * * p<.001 N=5052$

${ }^{\text {a }}$ Female as the reference group.

As supplementary analyses, we used the Finnish PISA 2015 data $(N=5430)$ and investigated whether inquiry-based science teaching practices (a close concept to student-oriented teaching practices) in science lessons might be related with students' learning outcomes in scientific literacy. Age, gender, the index of ESCS, and teacher-directed science instruction were controlled for. The results are shown in Supplementary Table 2. Frequent inquiry-based science teaching practices were associated with students' weaker performance in scientific literacy $(\beta=-0.075, p<.001)$. Moreover, frequent teacher-directed science instruction was related to students' better performance in scientific literacy $(\beta=0.19, p<.001)$.

Supplementary Table 1. The goodness-of-fit statistics of the structual equation models.

\begin{tabular}{lllllll}
\hline & \multicolumn{6}{c}{ Goodness-of-fit statistics } \\
\cline { 2 - 7 } & $\chi^{2}$ value & $d f$ & $p$ & TLI & CFI & RMSEA \\
\hline Model 1 & 15.377 & 25 & 0.932 & 1.000 & 1.000 & 0.000 \\
Model 2a & 19.451 & 29 & 0.909 & 1.000 & 1.000 & 0.000 \\
Model 2b & 19.013 & 33 & 0.975 & 1.000 & 1.000 & 0.000 \\
Model 2c & 22.843 & 33 & 0.907 & 1.000 & 1.000 & 0.000 \\
Model 2d & 28.012 & 33 & 0.714 & 1.000 & 1.000 & 0.000 \\
Model 2e & 27.326 & 33 & 0.745 & 1.000 & 1.000 & 0.000 \\
Model 2f & 23.787 & 33 & 0.880 & 1.000 & 1.000 & 0.000 \\
Model 3 & 23.970 & 33 & 0.875 & 1.000 & 1.000 & 0.000 \\
Model 4 & 115.889 & 80 & 0.005 & 1.000 & 1.000 & 0.009 \\
\hline
\end{tabular}

RMSEA = the Root Mean Square Error of Approximation.

$\mathrm{CFI}=$ the Comparative Fit Index.

$\mathrm{TLI}=$ the Tucker Lewis Index. 
Supplementary Table 2 . The standardized regression coefficients $(\beta)$ with $95 \%$ confidence intervals (CI) of structural equation models, when predicting scientific literacy by inquirybased teaching in PISA 2015 data.

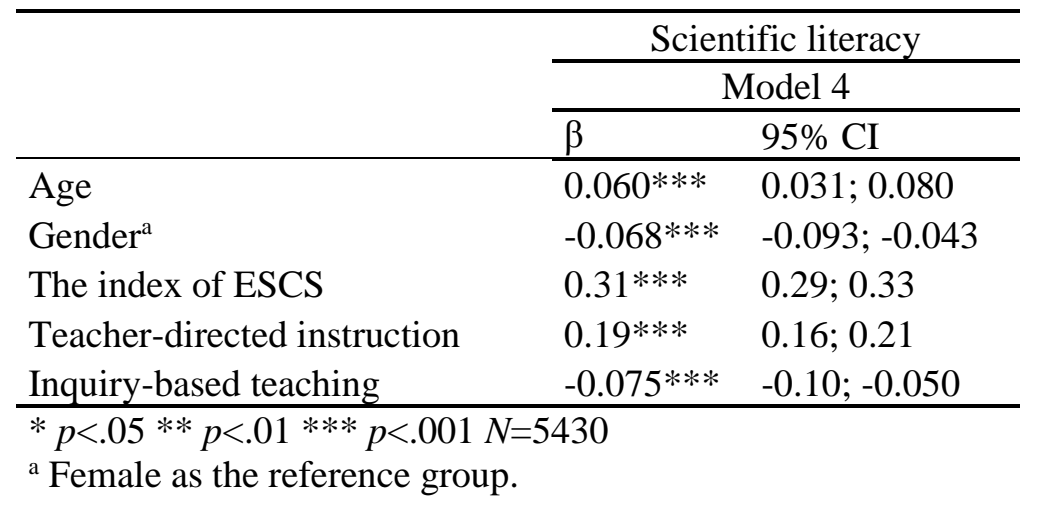

The goodness-of-fit statistics of all the structural equation models are shown in Supplementary Table 1. The goodness-of-fit was excellent in all the models ( $C F I=1.000$; $T L I=1.000 ;$ RMSEA=[0.000; 0.009]).

\section{Discussion and conclusion}

This study showed that frequent student-oriented or inquiry-based teaching practices were associated with students' weaker outcomes in mathematics and science. This finding was highly in line with previous studies conducted in other countries (Albanese \& Mitchell, 1993; Chall, 2000; Furtak \& Kunter, 2012; Gao et al., 2014; Kirschner et al., 2006; Klahr \& Nigam, 2004; Mayer et al., 2004; Moreno, 2004; Schaal \& Bogner, 2005; Sturm \& Bogner, 2008; Tuovinen \& Sweller, 1999). Furthermore, the adverse effect of frequent studentoriented teaching on learning outcomes was particularly adverse among students with risky background characteristics (i.e. risky family structure, low family wealth, low maternal education, immigrant status, student's previous truancy behavior at school). All the findings were controlled for age, gender, parental socioeconomic factors, and the frequency of teacherdirected instruction in the classroom. Taken together, student-oriented teaching appeared to significantly expand the gaps in the learning outcomes between students with and without risky background characteristics. The findings are in line with previous findings (e.g. Connor, et al., 2004; Kirschner et al., 2006; Vanlaar et al., 2016; Von Secker \& Lissitz, 1999; Zohar \& Dori, 2003). To the best of our knowledge, this study is the first to demonstrate these associa- 
tions in a large and nationally representative sample and standardized measures of learning outcomes. This gives stronger evidence on these associations and increases the societal relevance of the findings.

The negative association of student-oriented and inquiry-based teaching practices with cognitive learning outcomes may proceed via working memory overload. Specifically, the most important phase of learning takes place in working memory. That is, using working memory, the student identifies the structure of the learning task, selects relevant pieces of information from the learning material, and compares the new information to his/her previous knowledge (Kirschner, 2002; Van Merriënboer \& Ayres, 2005). Further, by using working memory, the student organizes the new pieces of information into coherent schemas (Kirschner, 2002; Van Merriënboer \& Ayres, 2005; Kirschner et al., 2006). Finally, the schemas are moved to the long-term memory, where the student can retain the new information later (Kirschner, 2002; Van Merriënboer \& Ayres, 2005). Importantly, however, working memory has a limited capacity, so that overloading working memory considerably decreases the opportunities for learning (Kalyuga et al., 2003; Kirschner, 2002; Kirschner et al., 2006).

It has been suggested that student-oriented teaching practices may contribute to working memory overload. Firstly, student-oriented teaching commonly includes students' independent problem-solving and self-directed investigations (Schunk, 2008; Terhart, 2003). That is, students are provided with only some pieces of information at a time and, in many cases, the new pieces of information may not be consistently linked with student's previous knowledge (Kirschner et al., 2006). Secondly, student-oriented teaching may direct students' attention to such school practices that are unrelated to the content of the learning material (Kirschner et al., 2006), for example, social interactions or technical use of electronic devices.

Historically, one fundamental assumption of the curricula reforms has been that student-oriented teaching could increase the equality in learning outcomes between students coming from different backgrounds (Von Secker \& Lissitz, 1999). Contrary to this, however, our findings revealed that the effect of student-oriented teaching on mathematical performance was particularly adverse among students with risky background characteristics. Specifically, we found that frequent student-oriented teaching had particularly adverse effect on students' mathematical performance (i) among boys, (ii) among first- or second-generation immigrants, (iii) among students coming from one-parent families or students who were not 
living with their parents, (iv) among students coming from economically poor families, (v) among students with a low-educated mother, and (vi) among students with previous truancy behavior at school. Moreover, we found that the effect of student-oriented teaching became more adverse when the total cumulative number of risk factors increased. Taken together, in accordance with previous suggestions (Connor, et al., 2004; Kirschner et al., 2006; Vanlaar et al., 2016; Von Secker \& Lissitz, 1999; Zohar \& Dori, 2003), our findings indicated that student-oriented teaching expanded the gaps in the learning outcomes between students coming from different backgrounds.

There are several explanations why student-oriented teaching may have particularly adverse effect on learning among students with risky background. Specifically, studentoriented teaching practices require a variety of neurocognitive skills from the student (Kim \& Davies, 2014). For example, in order to be able to regulate one's learning process so that it might result in efficient learning, comparatively high levels of autonomy, self-directedness, self-inhibition, concentration skills, initiative, and flexibility are required from the student. However, not all students possess these skills (Kim \& Davies, 2014), especially students coming from low-SES families (Caro et al., 2016; Cassidy, 2000; Miech, Esses, \& Goldsmith, 2001; Von Secker \& Lissitz, 1999), students with low previous school achievements (Pintrich \& de Groot, 1990; Von Secker \& Lissitz, 1999; Zohar \& Dori, 2003), and students who do not have necessary prior skills for self-directed learning (Kirschner, Sweller \& Clark, 2006). For example, immigrant students or students, who have skipped some lessons, may not have developed necessary learning routines, so that they would be able to regulate their learning process themselves. Finally, self-regulation is shown to be at a lower level among boys than girls in early adolescence (Raffaelli et al., 2005).

In the present study, there were some methodological limitations that are necessary to be taken into consideration. Firstly, we had data available on student-oriented teaching practices only in mathematics lessons. Hence, our results cannot be directly generalized to other school disciplines. However, our supplementary analyses revealed that frequent inquiry-based teaching practices (a close concept to student-oriented teaching practices) in science lessons were related to students' weaker performance in scientific literacy. Moreover, it has been found that the effect of teacher-directed instruction is more positive in reading lessons than mathematics lessons (Hattie, 2009). Hence, this implies that frequent student-oriented practices may potentially have even more adverse effect on learning in some other subjects than 
mathematics. The second limitation was that the study design was cross-sectional. Hence, any firm conclusions cannot be made about the temporal or causal relationships between studentoriented teaching and mathematical performance. Thirdly, the frequency of student-oriented teaching practices during mathematics lessons was assessed with questionnaires filled by students. Thus, there may have been some subjective bias in the estimated frequency of studentoriented teaching practices.

In conclusion, our findings showed that frequent student-oriented teaching practices in mathematics lessons were associated with students' weaker mathematical performance in Finland. Furthermore, the adverse effect of frequent student-oriented teaching on mathematical performance was particularly adverse among students with risky background characteristics. Taken together, student-oriented teaching appeared to expand the gaps in the learning outcomes between students coming from different backgrounds. In practice, it may not be reasonable to increase student-oriented teaching strategies in mathematics lessons. It should be taken into consideration that students coming from risky backgrounds may have a lower level of self-directedness and they may need particularly much teacher's support and guidance. Those students should not be given learning tasks that require a high amount of independent working. Further, they may need especially strong guidance when setting their learning goals, scheduling their work, and organizing their learning processes into smaller phases through which they can reach their learning goals.

\section{References}

Albanese, M. A., \& Mitchell, S. (1993). Problem-based learning: A review of literature on its outcomes and implementation issues. Academic Medicine-Philadelphia, 68, 52-52.

Bransford, J., Brown, A., \& Cocking, R. (Eds.). (2000). How people learn: Brain, mind, experience, and school (Expanded ed.). Washington, D. C.: National Academy Press.

Breen, R., Luijkx, R., Müller, W., \& Pollak, R. (2010). Long-term trends in educational inequality in Europe: Class inequalities and gender differences. European Sociological Review, 26, 31-48.

Caro, D. H., Lenkeit, J., \& Kyriakides, L. (2016). Teaching strategies and differential effectiveness across learning contexts: Evidence from PISA 2012. Studies in Educational Evaluation, 49, 30-41. https://doi.org/10.1016/j.stueduc.2016.03.005 
Cassidy, T. (2000). Social background, achievement motivation, optimism and health: a longitudinal study. Counselling Psychology Quarterly, 13, 399-412. https://doi.org/10.1080/713658501

Chall, J. S. (2000). The Academic Achievement Challenge: What Really Works in the Classroom. Guilford Publications, New York, United States.

Cobern, W. W., Schuster, D., Adams, B., Applegate, B., Skjold, B., Undreiu, A., \& Gobert, J. D. (2010). Experimental comparison of inquiry and direct instruction in science. Research in Science \& Technological Education, 28, 81-96. https://doi.org/10.1080/02635140903513599

Connor, C. M., Morrison, F. J., \& Katch, L. E. (2004). Beyond the reading wars: exploring the effect of child-instruction interactions on growth in early reading beyond the reading wars: exploring the effect of child-instruction interactions on growth in early reading. Scientific Studies of Reading, 8, 305-336. https://doi.org/10.1207/s1532799xssr0804_1

Creemers, B. P. M. (2006). The importance and perspectives of international studies in educational effectiveness. Educational Research and Evaluation, 12, 499-511. https://doi.org/10.1080/13803610600873978

Eamon, M. K. (2005). Social-demographic, school, neighborhood, and parenting influences on the academic achievement of Latino young adolescents. Journal of Youth and Adolescence, 34, 163-174. https://doi.org/10.1007/s10964-005-3214-x

Epstein, S., Roberts, E., Sedgwick, R., Polling, C., Finning, K., Ford, T., .. \& Downs, J. (2019). School absenteeism as a risk factor for self-harm and suicidal ideation in children and adolescents: a systematic review and meta-analysis. European Child \& Adolescent Psychiatry, 1-20.

The Finnish National Agency for Education (Opetushallitus) (2004). Perusopetuksen opetussuunnitelman perusteet 2004. Vammalan Kirjapaino Oy, Finland.

The Finnish National Agency for Education (Opetushallitus) (2016). Perusopetuksen opetussuunnitelman perusteet 2014. Helsinki: Edita, Finland.

Furtak, E. M., \& Kunter, M. (2012). Effects of autonomy-supportive teaching on student learning and motivation. The Journal of Experimental Education, 80, 284-316. https://doi.org/10.1080/00220973.2011.573019

Gao, S. (2014). Relationship between science teaching practices and students' achievement in Singapore, Chinese Taipei, and the US: An analysis using TIMSS 2011 data. Frontiers of Education in China, 9, 519-551. https://doi.org/10.3868/s110-003-014-0043-x 
Griner, A. C., \& Stewart, M. L. (2013). Addressing the achievement gap and disproportionality through the use of culturally responsive teaching practices. Urban Education, 48 , 585-621. https://doi.org/10.1177/0042085912456847

Guthrie, J. T., \& Wigfield, A. (2000). Engagement and motivation in reading. In M. L. Kamil, P. B. Mosenthal, P. D. Pearson, \& R. Barr (Eds.), Handbook of reading research: (Vol. III. pp. 403-418). London: Laurence Erlbaum Associates.

Hansen, K. Y., \& Gustafsson, J. E. (2019). Identifying the key source of deteriorating educational equity in Sweden between 1998 and 2014. International Journal of Educational Research, 93, 79-90.

Hao, S., \& Johnson, R. L. (2013). Teachers' classroom assessment practices and fourthgraders' reading literacy achievements: an international study. Teaching and Teacher Education, 29, 53-63. https://doi.org/10.1016/j.tate.2012.08.010

Hattie, J. A. C. (2009). Visible learning. An synthesis of over 800 meta-analyses relating to achievement. Routledge: Oxon.

Heine, C., \& Slone, M. (2008). The impact of mild central auditory processing disorder on school performance during adolescence. Journal of School Health, 78, 405-408.

Hong, S., Yoo, S. K., You, S., \& Wu, C. C. (2010). The reciprocal relationship between parental involvement and mathematics achievement: Autoregressive cross-lagged modeling. The Journal of Experimental Education, 78, 419-439.

Hu, L. T., \& Bentler, P. M. (1999). Cutoff criteria for fit indexes in covariance structure analysis: Conventional criteria versus new alternatives. Structural Equation Modeling: A Multidisciplinary Journal, 6, 1-55.

Hurmerinta, E., \& Vitikka, E. (2011). Kansainväliset opetussuunnitelmasuuntaukset. Opetushallitus: Raportit ja selvitykset 2011:4. Tampereen Yliopistopaino Oy.

Huurre, T., Lintonen, T., Kaprio, J., Pelkonen, M., Marttunen, M., \& Aro, H. (2010). Adolescent risk factors for excessive alcohol use at age 32 years. A 16-year prospective follow-up study. Social Psychiatry and Psychiatric Epidemiology, 45, 125-134. https://doi.org/10.1007/s00127-009-0048-y

International Labour Organization (ILO) (2007). Resolution concerning updating the International Standard Classification of Occupations. Derived from http://www.ilo.org/public/english/bureau/stat/isco/docs/resol08.pdf, last accessed 9 August 2018. 
Jaggers, J. W., Robison, S. B., Rhodes, J. L., Guan, X., \& Church, W. T. (2016). Predicting adult criminality among Louisiana's urban youth: Poverty, academic risk, and delinquency. Journal of the Society for Social Work and Research, 7, 89-116.

Kalyuga, S., Ayres, P., Chandler, P., \& Sweller, J. (2003). The expertise reversal effect. Educational Psychologist, 38, 23-31.

Kim, A. K., \& Davies, J. (2014). A teacher's perspective on student centred learning: Towards the development of best practice in an undergraduate tourism course. Journal of Hospitality, Leisure, Sport \& Tourism Education, 14, 6-14. https://doi.org/10.1016/j.jhlste.2013.12.001

Kirschner, P. A. (2002). Cognitive load theory: Implications of cognitive load theory on the design of learning. Learning and Instruction, 12, 1-10. https://doi.org/10.1016/S0959$\underline{4752(01) 00014-7}$

Kirschner, P. A., Sweller, J., \& Clark, R. E. (2006). Why minimal guidance during instruction does not work: an analysis of failure of constructivist, discovery, problem-based, experimental, and inquiry-based teaching. Educational Psychologist, 41, 75-86. https://doi.org/10.1207/s15326985ep4102_1

Klahr, D., \& Nigam, M. (2004). The equivalence of learning paths in early science instruction: Effects of direct instruction and discovery learning. Psychological Science, 15, 661-667. https://doi.org/10.1111/j.0956-7976.2004.00737.x

Kyriakides, L., Christoforou, C., \& Charalambous, C. Y. (2013). What matters for student learning outcomes: a meta-analysis of studies exploring factors of effective teaching. Teaching and Teacher Education, 36, 143-152. https://doi.org/10.1016/j.tate.2013.07.010

Ladson-Billings, G. (1995). Toward a theory of culturally relevant pedagogy. American Educational Research Journal, 32, 465-491. https://doi.org/10.3102/00028312032003465

Lea, S. J., Stephenson, D., \& Troy, J. (2003). Higher education students' attitudes to studentcentered learning: beyond'educational bulimia'. Studies in Higher Education, 28, 321334. https://doi.org/10.1080/03075070309293

Li, M. (2006). High school completion and future youth unemployment: New evidence from High School and Beyond. Journal of Applied Econometrics, 21, 23-53. https://doi.org/10.1002/jae.817

Lipowsky, F., Rakoczy, K., Pauli, C., Drollinger-Vetter, B., Klieme, E., \& Reusser, K. (2009). Quality of geometry instruction and its short-term impact on students' under- 
standing of the Pythagorean theorem. Learning and Instruction, 19, 527- 537. https://doi.org/10.1016/j.learninstruc.2008.11.001

Lord, T. R. (2001). 101 reasons for using cooperative learning in biology teaching. The American Biology Teacher, 63, 30-38. https://www.jstor.org/stable/4451027

Mayer, R. (2004). Should there be a three-strikes rule against pure discovery learning? The case for guided methods of instruction. American Psychologist, 59, 14-19. http://dx.doi.org/10.1037/0003-066X.59.1.14

Miech, R., Essex, M. J., \& Goldsmith, H. H. (2001). Socioeconomic status and the adjustment to school: the role of self-regulation during early childhood. Sociology of Education, 74, 102-120. https://www.jstor.org/stable/2673165

Moreno, R. (2004). Decreasing cognitive load in novice students: Effects of explanatory versus corrective feedback in discovery-based multimedia. Instructional Science, 32, 99 113. https://doi.org/10.1023/B:TRUC.0000021811.66966.1d

National Research Council (2000). Inquiry and the national science education standards: A guide for teaching and learning. Washington, D. C.: National Academy Press.

Pintrich, P. R., \& de Groot, E. V. (1990). Motivational and self-regulated learning components of classroom academic performance. Journal of Educational Psychology, 82, $33-40$.

Pitkänen, T., Kokko, K., Lyyra, A. L., \& Pulkkinen, L. (2008). A developmental approach to alcohol drinking behaviour in adulthood: a follow-up study from age 8 to age 42. Addiction, 103, 48-68. https://doi.org/10.1111/j.1360-0443.2008.02176.x

Raffaelli, M., Crockett, L. J., \& Shen, Y. L. (2005). Developmental stability and change in self-regulation from childhood to adolescence. The Journal of Genetic Psychology, 166, 54-76. https://doi.org/10.3200/GNTP.166.1.54-76

Randler, C., \& Bogner, F. X. (2006). Cognitive achievements in identification skills. Journal of Biological Education, 40, 1-5. https://doi.org/10.1080/00219266.2006.9656038

Schaal, S., \& Bogner, F. X. (2005). Human visual perception - Learning at workstations. $\begin{array}{llll}\text { Journal of Biological } & \text { Education, } & \text { 32-37. }\end{array}$ https://doi.org/10.1080/00219266.2005.9656006

Schreiber, J. B., Nora, A., Stage, F. K., Barlow, E. A., \& King, J. (2006). Reporting structural equation modeling and confirmatory factor analysis results: A review. The Journal of Educational Research, 99, 323-338. https://doi.org/10.3200/JOER.99.6.323-338

Schunk, D. H. (2008). Learning Theories: An Educational Perspective. Merrill Prentice Hall: London, UK. 
Slominski, L., Sameroff, A., Rosenblum, K., \& Kasser, T. I. M. (2011). Longitudinal predictors of adult socioeconomic attainment: The roles of socioeconomic status, academic competence, and mental health. Development and Psychopathology, 23, 315-324.

Sturm, H., \& Bogner, F. X. (2008). Student-oriented versus Teacher-centred: The effect of learning at workstations about birds and bird flight on cognitive achievement and motivation. International Journal of Science Education, 30, 941-959. https://doi.org/10.1080/09500690701313995

Sweller, J. (2009). What human cognitive architecture tells us about constructivism. In Constructivist Instruction (pp. 139-155). Routledge.

Terhart, E. (2003). Constructivism and teaching: a new paradigm in general didactics? Journal of Curriculum Studies, 35, 25-44. https://doi.org/10.1080/00220270210163653

The Organisation for Economic Co-operation and Development (OECD) (1999). Classifying Educational Programmes: Manual for ISCED-97 Implementation in OECD Countries. OECD Publishing, Paris.

The Organisation for Economic Co-operation and Development (OECD) (2013). PISA 2012 Assessment and Analytical Framework: Mathematics, Reading, Science, Problem Solving and Financial Literacy. PISA, OECD Publishing.

The Organisation for Economic Co-operation and Development (OECD) (2014). PISA 2012 Technical Report. PISA, OECD Publishing.

The Organisation for Economic Co-operation and Development (OECD) (2016): PISA 2015 Results (Volume I): Excellence and Equity in Education, PISA. Paris: OECD Publishing.

Tuovinen, J. E., \& Sweller, J. (1999). A comparison of cognitive load associated with discovery learning and worked examples. Journal of Educational Psychology, 91, 334-341. http://dx.doi.org/10.1037/0022-0663.91.2.334

Vanlaar, G., Kyriakides, L., Panayiotou, A., Vandecandelaere, M., McMahon, L., De Fraine, B., \& Van Damme, J. (2016). Do the teacher and school factors of the dynamic model affect high-and low-achieving student groups to the same extent? A cross-country study. Research Papers in Education, 31, 183-211.

Von Secker, C. R., \& Lissitz, R. W. (1999). Estimating the impact of instructional practices on student achievement in science. Journal of Research in Science Teaching, 36, 1110-1126. $\quad$ https://doi.org/10.1002/(SICI)1098-2736(199912)36:10<1110::AID$\underline{\text { TEA4 }>3.0 . C O ; 2-T}$ 
Wallin, A. S., Koupil, I., Gustafsson, J. E., Zammit, S., Allebeck, P., \& Falkstedt, D. (2019). Academic performance, externalizing disorders and depression: 26,000 adolescents followed into adulthood. Social Psychiatry and Psychiatric Epidemiology, 54, 977986.

Zohar, A., \& Dori, Y. J. (2003). Higher order thinking skills and low-achieving students: Are they mutually exclusive. Journal of the Learning Sciences, 12, 145-181. https://doi.org/10.1207/S15327809JLS1202_1

Received: $11-10-2019$

Accepted: 09-04-2020 